\title{
Evaluation of Efficacy of Different Bioagents and Fungicides against Rhizoctonia solani (Kuhn)
}

\author{
Ramji Lal Meena ${ }^{1}$, Shankar Lal Godara ${ }^{1}$, Ashok Kumar Meena ${ }^{1}$ and \\ Prabhu Narayan Meena ${ }^{1,2 *}$ \\ ${ }^{1}$ College of Agriculture, Department of Plant Pathology, Swami Keshwanand Rajasthan \\ Agricultural University, Bikaner - 334 006, Rajasthan, India \\ ${ }^{2}$ ICAR-Central Research Institute for Jute and Allied Fibres, Barrackpore, \\ Kolkata - 700 120, India
}

*Corresponding author

\begin{abstract}
A B S T R A C T
Mungbean (Vigna radiate L.) is an important pulse crop in Indian continent. Mungbean is infected by several fungal, bacterial and viral diseases but foliar blight caused by Rhizoctonia solani considered as one of the most devastating diseases in the mungbean.

\section{Keywords}

Rhizoctonia solani,

Bioagents,

Fungicides and

Mungbean

Article Info

Accepted:

20 August 2018

Available Online:

10 September 2018

The main aim of this study was to find out the effective fungicides and bioagents for the timely management of R.solani. Efficacy of tebuconazole $50 \%+$ trifloxystrobin $25 \% \mathrm{WG}$, carbendazim $12 \%+$ mancozeb $63 \% \mathrm{WP}, T$. harzianum and P. fluorescens were assessed under in vitro and in vivo conditions against $R$. solani. Among the treatments, the treatment consisting with tebuconazole $50 \%$ + trifloxystrobin $25 \%$ WG seed treatment $\left(1.5 \mathrm{~g} / \mathrm{kg}^{-1}\right.$ seed) and soil drenching $\left(1.5 \mathrm{~g} / \mathrm{lt}^{-1}\right.$ water) was found most effective in minimizing the foliar blight incidence $(10.76 \%)$, disease inhibition $(83.70 \%)$ and gave highest seed yield $\left(14.20 \mathrm{q} / \mathrm{ha}^{-1}\right)$ in mungbean followed by treatment consisting with seed treatment of carbendazim 12\% + mancozeb 63\% WP @ $2 \mathrm{~g} \mathrm{~kg}^{-1}$ and soil drenching of carbendazim $12 \%$ + mancozeb 63\% WP @ 2g lt ${ }^{-1}$ water $(12.60 \%)$, (80.91\%) and $\left(13.50 \mathrm{q} / \mathrm{ha}^{-1}\right)$ as compared to control $\left(66.00 \%\right.$ and $\left.5.70 \mathrm{q}^{-\mathrm{ha}^{-1}}\right)$ respectively. while, in case of bioagents, seed treatment with $T$. harzianum@ $10 \mathrm{~g} / \mathrm{kg}^{-1}$ and combination with soil application @ 10 $\mathrm{kg} \mathrm{ha}{ }^{-1}$ found most effective in minimizing the foliar blight incidence $(25.13 \%)$ and disease inhibition (61.92\%) followed by seed treatment with P. fluorescens@ $10 \mathrm{~g} / \mathrm{kg}^{-1}$ and combination with soil application $10 \mathrm{~kg} \mathrm{ha}^{-1}(33.10 \%)$ and $(49.85 \%)$ respectively, as compared to untreated control.
\end{abstract}

\section{Introduction}

Mungbean/greengram [Vigna radiate (L.) Wilczek] is one of the most important pulse crop. It is grown in almost all parts of the country. It has proved to be an ideal crop for the spring, summer and kharif season.
Mungbean belongs to family leguminaceae and sub family papilionaceae. It is the third important pulse crop in the country after chickpea and pigeonpea and covers an area about 29.36 lakh ha with production of 13.90 lakh tonnes (Anonymous, 2015). Mungbean is mainly grown in the states of Rajasthan, 
Maharashtra, Madhya Pradesh, Orissa, Andhra Pradesh, Tamil Nadu and Uttar Pradesh. In Rajasthan, the total area under cultivation of mungbean was 13.68 lakh ha with the annual production 6.02 lakh tonnes and productivity of $441 \mathrm{kgha}^{-1}$ (Anonymous, 2016). Mungbean is mainly grown in Bikaner, Jaipur, Bhilwara, Bharatpur, Jodhpur, Kota, Ajmer and Udaipur districts of Rajasthan. It is erect, sub erect deep rooted crop. It requires hot climate and has the capacity to tolerate moisture stress. De-Candolle believes that mungbean has been originated in India. It is grown in these areas since prehistoric period.

This global crop, encounters a number of operational constraints, including pests and diseases that limit its production and yield potentials from seedling to harvest and often provoking grain yield loss of over 35 per cent (Asiwe, 2006). Brien et al., (2008) identified Rhizoctonia solani (Kuhn) on the basis of morphological features as causal pathogen on mungbean. $R$. solani is known to affect many crops. Rhizoctonia solani survives in soil as dormant mycelium and sclerotia which served as primary source of inoculum. It can survive even in the absence of host on dead organic matter or by producing sclerotia or thick walled brown hyphae in plants debris. Sclerotial bodies which are viable over the years. Rhizoctonia solani (Kuhn), inciting of foliar blight of mungbean was described by the De Candolle, (1815).

In western Rajasthan the incidence of $R$. solani is very severe and hampered the yield production of mungbean crop. Now, it is a well-known soil inhabiting plant pathogen including mungbean, capable of attacking a tremendous range of host plants throughout the world and causing seed decay, damping off, stem cankers, root rots, fruit decay and foliage diseases. Among the diseases, foliar blight is most severe at seedling and vegetative stage. The disease is characterized by oval or spindle shaped brown-black lesions having length ranging from $0.2-8 \mathrm{~cm}$ at soil level near collar region and girdling the basal portion of the stem. Under humid conditions the lesions develop rapidly and coalesces leading to extensive blighting and defoliation (Allen and Lenne, 1998). Web blight induced by Rhizoctonia solani Khun (Thanatephorus cucumeris), is a common and wide spread disease on mungbean. The incidence of disease varied from 17-90 per cent in India and 30-40 per cent in Rajasthan, Jhamaria and Sharma (2002). The optimal physiological condition for growth and sclerotia production depends upon isolates of $R$. solani and lower and higher optimal have been reported for various isolates (Goswami et al., 2011).

The fungicides presently recommended to manage these diseases provide protection for limited period. The continuous use of traditional fungicides may cause bioaccumulation of the toxic residues besides giving rise to resistant strains. Increased public concern about pesticide utilization and the health hazards necessitates the exploitation of alternative methods of disease control. Now a day's research on disease management all over the world is mostly towards biological control or application of combined treatment of bioagent and fungicide. In the last three decades, a lot of researches have been carried out on the antagonistic nature of several fungal and bacterial biocontrol agents (Papavizas, 1985; Couillerot et al., 2008). Blakeman and Fokkema (1982) reported that Trichoderma species are the well-known antagonists, particularly in the soil and that they are involved in competition, antibiosis and hyperparasitic interactions, which makes them the most effective biocontrol agents even on foliar surfaces. Priyanka et al., (2017) reported that cowpea web blight caused by Rhizoctoma solani (Kuhn) is an emerging 
disease in cowpea growing areas of Rajasthan and causes considerable yield losses. Further, they assessed the antagonistic potentiality of locally isolated eleven fungal and six bacterial antagonists against $R$. solani. Four Trichoderma strains i.e., T. harzianum (ThBKN) T. harzianum (Th-JJN). T. viride (BKN) and T. harzianum (JPR) and two bacterial antagonists' i.e., B. subtilis (Bs$\mathrm{BKN}$ ) and $P$. fluorescens (Pf-BKN) were reported to be effective against $R$. solani.

They are less detrimental, eco-friendly and safer than synthetic pesticides (Hashim and Devi, 2003). Hence, the present investigation was undertaken to find out the potentiality of new fungicides molecules and bioagents to develop an effective module of disease management against foliar blight disease of Mungbean.

\section{Materials and Methods}

Evaluation of antagonistic potential of fungal and bacterial bioagents against $R$. solani under in vitro conditions

The experiments were carried out at department of Plant Pathology, College of Agriculture, SKRAU, Bikaner. The native isolate of $T$. viride $(\mathrm{Tv}-\mathrm{BKN})$ identified through ITCC, IARI, New Delhi, Accession number- 7424-09, T. harzianum (Th-BKN), P. fluorescens (Pf-18) and B. subtilis (Bs-15) were tested in vitro by dual culture technique (fungus) and paper disc method (bacteria) to know their antagonistic activities on the growth of $R$. solani. In dual culture technique one mycelial disc ( $5 \mathrm{~mm}$ diameter) of each of the pathogen and antagonist was kept on the surface of potato dextrose agar medium in Petri dishes at $3 \mathrm{~cm}$ apart from centre.

The inoculated Petri dishes were incubated at $26 \pm 1{ }^{\circ} \mathrm{C}$ for 7 days. Three replications were kept for each fungal antagonist. In case of control, the Petri dishes were inoculated with mycelial discs of the test pathogen only. The mycelial growth of test pathogen was measured after 4 days of inoculation. The inhibition of mycelial growth of the pathogen was calculated by using the following formula: [Per cent inhibition $=\mathrm{C}-\mathrm{T} / \mathrm{C}$ ] $\times$ $100, \mathrm{C}=$ Mycelial growth of $R$. solani in control $(\mathrm{mm}), \mathrm{T}=$ Mycelial growth of $R$. solani in presence of antagonist (mm).

Similarly, for bacterial bioagents, paper disc method (Loo et al., 1945) was followed. Circular discs ( $5 \mathrm{~mm}$ dia.) of Whatmanfilter (No. 42) were cut and dipping in suspension of bacterial antagonists then placed $1 \mathrm{~cm}$ inward from the periphery of Petri dishes at four equal distance end places, having in the centre the inoculums of the pathogen. The inoculated dishes were placed in an incubator at $26 \pm 1{ }^{0} \mathrm{C}$ for a week and observations were recorded. The experiments were repeated thrice. The inhibitions of mycelia growth by the respective bacterial antagonists were calculated.

Evaluation of inhibitory effect of fungicides on growth of $R$. solani under in vitro conditions

Two fungicides Tebuconazole $50 \%+$ Trifloxystrobin $25 \% \mathrm{WG}$ and Carbendazim $12 \%$ + Mancozeb $63 \%$ WP were used at different concentrations (10 ppm, 25 ppm, 50 ppm, $100 \mathrm{ppm}$ ) against $R$. solanion potato dextrose agar (PDA) to ascertain the inhibitory effect of fungicides by using poison food technique.

The required quantity of respective fungicide was added in PDA containing conical flask, then dissolves properly and poured into Petri dishes. Mycelial disc (5 $\mathrm{mm}$ diameter) of pathogen was kept on the surface of potato dextrose agar medium. Three replications of each treatment along with control were 
carried out in completely randomized design (CRD), incubated at $30 \pm 1{ }^{0} \mathrm{C}$ for 7 days in BOD incubator and observations were recorded. The radial growth of fungus in each treatment (per cent growth inhibition) was calculated by using formula. $[\mathrm{PGI}=\mathrm{C}-\mathrm{T} / \mathrm{C}]$ $\times 100$, Where, PGI $=$ Per cent growth inhibition; $\mathrm{C}=$ Linear area of test fungus in control $(\mathrm{mm})$ and $\mathrm{T}=$ Linear area of test fungus in respective treatment $(\mathrm{mm})$

\section{Evaluation of fungicides and bioagents against $R$. solani under in vivo conditions}

Field experiments were conducted in the cropping season of 2017 at the Research farm of college of Agricultural, Swami Keswananad Agricultural University (SKRAU), Bikaner. The soil of Bikaner is dominant in sandy loam, low to medium in available $\mathrm{N}, \mathrm{P}$, and low in $\mathrm{K}$ content. The experiments were carried out on fixed sites in under arid agro climatic zones of Rajasthan. The experiment was conducted to study the efficacy of selective bioagents and fungicides as seed treatment, drenching and soil application for the management of $R$. solani disease of mungbean. The experiment was conducted in randomized block design (RBD) with three replications using the susceptible cultivar 'SML-668' in 3x4 m plot size with row to row spacing at $30 \mathrm{~cm}$ and plant to plant spacing at $10 \mathrm{~cm}$ during Kharif. The recommended dose of fertilizers @ $20 \mathrm{~kg} \mathrm{~N}$ and $40 \mathrm{~kg} \mathrm{P} \mathrm{ha}^{-1}$ were applied. The crop was sown during the second week of June. Three irrigations were applied at different crop stages and weeding was done as and when required. The talc based formulations of fungal and bacterial bioagents were taken from experiential learning lab mass production of bio-agents, Department of Plant Pathology, College of Agriculture, SKRAU, Bikaner. Similarly, Fungicides Tebuconazole $50 \%+$ Trifloxystrobin $25 \% \quad \mathrm{WG}$ and Carbendazim 12\% + Mancozeb 63\% WP were used. Two drenching of chlorpyriphos @ $2.41 \mathrm{ha}^{-1}$ was applied for termite control. Different modules of treatments comprising fungal antagonists and fungicides are as follows: $\mathrm{T}_{1}$-Seed treatment with Tebuconazole 50\% + Trifloxystrobin 25\% WG@1.5 $\mathrm{g} \mathrm{kg}^{-1}$; $\mathrm{T}_{2}$ - Seed treatment with Carbendazim 12\% + Mancozeb 63\% WP@

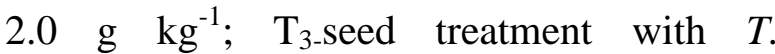
harzianum. @ $10 \mathrm{~g} \mathrm{~kg}^{-1} ; \mathrm{T}_{4^{-}}$Seed treatment with P.fluorescens@10 g kg-1 ; $_{5}$-Drenching of Tebuconazole 50\%+ Trifloxystrobin 25\% WG @ $1.5 \mathrm{~g} \mathrm{l}^{-1}$ water; $\mathrm{T}_{6}$-Drenching of Carbendazim 12\% + Mancozeb 63\%@2.0 g $\mathrm{I}^{-1}$ water; $\mathrm{T}_{7-}$ Soil application of $T$. harzianum @ $10 \mathrm{~kg} \mathrm{ha}^{-1}$ with $50 \mathrm{~kg}$ vermicompost; $\mathrm{T}_{8}$ Soil application of P. fluorescens @ $10 \mathrm{~kg}$ ha $^{-1}$ with $50 \mathrm{~kg}$ vermicompost; $\mathrm{T}_{9^{-}}$Seed treatment with Tebuconazole $50 \%+$ Trifloxystrobin 25\% WG @ $1.5 \mathrm{~g} \mathrm{~kg}^{-1}+$ Drenching of Tebuconazole 50\%+

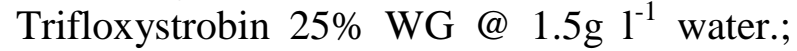
$\mathrm{T}_{10-}$ Seed treatment with Carbendazim $12 \%+$ Mancozeb 63\% WP @ $2.0 \mathrm{~g} \mathrm{~kg}^{-1}+$ Drenching of Carbendazim 12\%+ Mancozeb 63\%@2.0 $\mathrm{g} \mathrm{l}^{-1}$ water; $\mathrm{T}_{11^{-}}$Seed treatment with $T$. harzianum. @10 $\mathrm{g} \mathrm{kg}^{-1}+$ Soil application of T. harzianum @ $10 \mathrm{~kg} \mathrm{ha}{ }^{-1}$ with $50 \mathrm{~kg}$ vermicompost; $\mathrm{T}_{12}-$ Seed treatment with $P$. fluorescens@10 g kg-1 + Soil application of P. fluorescens @ $10 \mathrm{~kg} \mathrm{ha}^{-1}$ with $50 \mathrm{~kg}$ vermicompost; $\mathrm{T}_{13-}$ control. Observations on seedling mortality due to foliar blight and incidence on standing crop were recorded periodically and per cent disease incidence was calculated.

Disease incidence was worked out by the following formula. $\mathrm{DI}=[$ (No. of diseased plants) / (Total no. of plants) $\mathrm{x}$ 100], PDC = [(PDI in control - PDI in treatment) / (PDI in control) $x$ 100]. The yield obtained from each plot was recorded after threshing. Data were analysed afterarc sin transformation using software OPSTAT single factor analysis of variance (ANOVA). 


\section{Results and Discussion}

Evaluation of antagonistic potential of fungal and bacterial bioagents against $R$. solani under in vitro conditions

The results depicted from table 1 revealed that all biocontrol agents were found significantly superior in inhibiting the mycelial growth of $R$. solani over the control. Maximum percent growth inhibition was recorded in $T$. harzianum $(71.11 \%)$ strain followed by $T$. viride (64.44 \%). Similarly, the bacterial bioagents Pseudomonas fluorescens also found effective in reducing the mycelial growth of pathogen $(52.96 \%)$ followed by Bacillus subtilis $(40.00 \%)$ in compared to control. The similar observations on suppression of mycelial growth of $R$. solani pathogenic to mungbeen and certain other host plants by different microbial antagonists viz., Trichoderma spp., $P$. fluorescens, $B$. subtilis, etc. have been reported by various workers (Shalini et al., 2006, Wahyudi et al., 2011 and Reetha et al., 2014) that were harmony to our study. Meena and Gangopadhyay (2016) also evaluated antagonistic potentiality of twelve fungal and ten bacterial antagonists against Macrophomina phaseolina. They found that fungal antagonist $T$. viride and bacterial antagonist $P$. fluorescens significantly inhibited the mycelial growth of $M$. phaseolina in vitro conditions that also corroborated to our findings.

Evaluation of inhibitory effect of fungicides on growth of $R$. solani under in vitro conditions

Two fungicides tebuconazole $50 \%$ + trifloxystrobin $25 \% \mathrm{WG}$ and carbendazim $12 \%$ + mancozeb $63 \% \mathrm{WP}$ were tested on concentrations from $10 \mathrm{ppm}$ to $100 \mathrm{ppm}$ and compared with control. The results revealed that tebuconazole $50 \%+$ trifloxystrobin $25 \%$
WG fungicide gave maximum inhibition of mycelia growth of test fungus $11.00 \mathrm{~mm}$ on $100 \mathrm{ppm}$ followed by carbendazim $12 \%+$ mancozeb 63\% WP $12.00 \mathrm{~mm}$ after 3 days inoculation as compared to control $(90 \mathrm{~mm})$. While, after 5 and 7 days tebuconazole $50 \%+$ trifloxystrobin $25 \% \mathrm{WG}$ gave minimum mycelia growth $12.50 \mathrm{~mm}$ and $13.00 \mathrm{~mm}$ on $100 \mathrm{ppm}$ concentration solution followed by carbendazim $12 \%+$ mancozeb $63 \%$ WP $17.20 \mathrm{~mm}$ and $23.00 \mathrm{~mm}$ as compared to control. Similarly, maximum mycelial growth of $R$. solani was recorded in both the fungicides $69 \mathrm{~mm}$ and $74.50 \mathrm{~mm}$ at $10 \mathrm{ppm}$ concentrations solution after 7 days (Table 2). In both the concentration radial growth of fungus was checked after 5 and 7 days. Although, tebuconazole $50 \%+$ tarifloxystrobin $25 \% \mathrm{WG}$ was found most effective in compared to carbendazim $12 \%+$ mancozeb $63 \%$ WP. The minimum mean radial growth of tebuconazole $50 \%+$ trifloxystrobin $25 \%$ WG (12.16 mm) was recorded at $100 \mathrm{ppm}$ concentration solution. Manu et al., (2012) reported the systemic fungicides like Hexaconazole, Propiconazole, Difenconazole and Combi products, Avatar (Hexaconazole 4\% + Zineb 68\%), Nativo (Tebuconazole 50\% + Trifloxystrobin 25\%) and Vitavax power (Thiram $37.5 \%+$ Carboxin $37.5 \%$ ) showed complete inhibition of $S$. rolfsii at all the concentrations tested in finger millet. These fungicides combinations were also found effective against $R$. solani.

\section{Evaluation of fungicides and bioagents} against $R$. solani under in vivo conditions

The results depicted from (Table 3 ) indicated that fungicidal treatments consisting with tebuconazole $50 \%$ + trifloxystrobin $25 \% \mathrm{WG}$ seed treatment $\left(1.5 \mathrm{~g} / \mathrm{kg}^{-1}\right.$ seed $)$ and soil drenching $\left(1.5 \mathrm{~g} / \mathrm{lt}^{-1}\right.$ water) was found most effective in minimizing the foliar blight incidence $(10.76 \%)$ and disease inhibition $(83.70 \%)$ in mungbean followed by treatment 
consisting with seed treatment of carbendazim $12 \%$ + mancozeb 63\% WP @ $2 \mathrm{~g} / \mathrm{kg}^{-1}$ and soil drenching of carbendazim $12 \%+$ mancozeb 63\% WP @ 2g lt $\mathrm{t}^{-1}$ water $(12.60 \%)$ and $(80.91 \%)$ as compared to control $(66.00 \%)$ respectively. Similarly, seed treatment with tebuconazole 50\% + trifloxystrobin 25\% WG @ $1.5 \mathrm{~g} / \mathrm{kg}^{-1}$ also minimised the disease incidence of foliar blight (18.30\%) followed by seed treatment with carbendazim $12 \%+$ mancozeb $63 \%$ WP @ $2 \mathrm{~g} / \mathrm{kg}^{-1}(22.50 \%)$ as compared to other treatments.In case of bioagents, seed treatment with $T$. harzianum @ $10 \mathrm{~g} / \mathrm{kg}^{-1}$ and combination with soil application@ $10 \mathrm{~kg} \mathrm{ha}^{-1}$ minimized the foliar blight incidence $(25.13 \%)$ and disease inhibition (61.92\%) followed by seed treatment with P. flurescens @ $10 \mathrm{~g} / \mathrm{kg}^{-1}$ and combination with soil application $10 \mathrm{~kg} \mathrm{ha}^{-1}$ $(33.10 \%)$ and (49.85\%) respectively, as compared to control. Although resistant varieties can solve the problem for the management of soil borne diseases to a greater extent but they do not maintain their resistance for long duration due to constant variations in nature of pathogen, the changing role of microorganisms in soil and other variable soil factors. Chemical control is necessary for many diseases at present, but undesirable and even inadequate as a long term solution to crop health. Therefore, inhibition and control of phytopathogens by biological means are more economical and advantageous over chemicals (Cothran et al., 2013). Antibiotics secreted by antagonistic organisms can be utilized for inhibiting the development of the pathogen in soil, thereby, reducing the intensity of soil borne diseases incited by plant pathogenic organisms ultimately leading for biological control as stated by Harman et al., (2010) and Nawar (2008). The integration of seed treatment and soil drench of tebuconazole $50 \%+$ trifloxystrobin $25 \% \mathrm{WG}$ and application of bioagents i.e. T. harzianum and P. fluorescens was highly effective for the management of foliar blight. Seed treatments of bioagents were more effective than soil application for all the evaluated parameters also recorded similar findings. Seed treatment of fungicide was more effective than seed and soil application of bioagents. Seed treatment with $T$. harzianum and $P$. fluorescens significantly control the per cent disease incidence. The similar findings have been reported by Patel et al., (2014) and Kumari et al., (2012) that were similar to our studies.

Table.1 Effect of antagonists on mycelial growth of $R$. solaniin vitro

\begin{tabular}{|l|l|l|}
\hline Treatment & Mycelial growth $(\mathbf{m m})$ & Per cent Inhibition \\
\hline T. harzianum & $26.00(30.66) *$ & 71.11 \\
\hline T. viride & $32.00(34.45)$ & 64.44 \\
\hline P. fluorescens & $42.33(40.40)$ & 52.96 \\
\hline B. subtilis & $54.00(47.29)$ & 40.00 \\
\hline Control & $90.00(71.57)$ & - \\
\hline $\begin{array}{l}\text { S.Em } \pm \\
\text { CD } \mathbf{P}=\mathbf{0 . 0 5}\end{array}$ & 1.033 .29 & \\
$\mathbf{C V}(\boldsymbol{\%})$ & 3.66 & \\
\hline
\end{tabular}

* Figures in parentheses are angular transformed values 
Table.2 Effect of different concentration of fungicides on mycelial growth of $R$. solani

\begin{tabular}{|c|c|c|c|c|c|c|c|c|}
\hline \multirow{3}{*}{$\begin{array}{l}\text { Concentrationof } \\
\text { fungicides (ppm) }\end{array}$} & \multicolumn{8}{|c|}{ Mycelial growth(mm) after } \\
\hline & \multicolumn{2}{|c|}{3 days } & \multicolumn{2}{|c|}{5 days } & \multicolumn{2}{|c|}{7 days } & \multicolumn{2}{|c|}{ Mean } \\
\hline & A & $\mathrm{B}$ & A & $\mathrm{B}$ & A & B & A & B \\
\hline 10 & 44.00 & 57.00 & 63.00 & 65.00 & 69.00 & 74.50 & 58.66 & 65.50 \\
\hline 25 & 47.00 & 53.00 & 52.00 & 58.00 & 54.50 & 64.40 & 51.16 & 58.46 \\
\hline 50 & 26.00 & 27.20 & 28.00 & 30.00 & 30.60 & 35.00 & 28.20 & 30.73 \\
\hline 100 & 11.00 & 12.00 & 12.50 & 17.20 & 13.00 & 23.00 & 12.16 & 17.40 \\
\hline Control & 90.00 & 90.00 & 90.00 & 90.00 & 90.00 & 90.00 & 90.00 & 90.00 \\
\hline $\mathrm{S} \mathrm{Em} \pm 0.51$ & 0.60 & 0.76 & 0.821. & $3 \quad 1.0$ & 0.83 & 0.81 & & \\
\hline $\mathrm{CD} P=0.05$ & 1.64 & 1.92 & 2.44 & 3.9 & 3.49 & 1.13 & 1.17 & \\
\hline $\mathrm{CV}(\%)$ & 2.05 & 2.18 & 2.70 & 4.1 & 3.30 & 4.08 & 3.85 & \\
\hline
\end{tabular}

A. Tebuconazole 50\% + Trifloxystrobin 25\% WG; B. Carbendazim 12\% + Mancozeb 63\% WP

Table.3 Management of foliar blight of mungbean with different bioagents and fungicide under field conditions

\begin{tabular}{|c|c|c|c|c|}
\hline Treatment & Dose & $\begin{array}{l}\text { Disease } \\
\text { incidence (\%) }\end{array}$ & $\begin{array}{l}\text { Disease } \\
\text { inhibition }(\%)\end{array}$ & $\begin{array}{l}\text { Yield } \\
\left(\text { qha }^{-1}\right)\end{array}$ \\
\hline $\begin{array}{l}T_{1} \text { - Tebuconazole } 50 \%+ \\
\text { Trifloxystrobin } 25 \% \text { WG }\end{array}$ & $\mathrm{ST} @ 1.5 \mathrm{~g} / \mathrm{kg}^{-1}$ & $18.30(25.33)^{*}$ & 72.27 & 12.30 \\
\hline $\begin{array}{l}\mathrm{T}_{2}-\text { Carbendazim } 12 \%+ \\
\text { Mancozeb } 63 \% \mathrm{WP}\end{array}$ & ST @ $2 \mathrm{~g} / \mathrm{kg}^{-1}$ & $22.50(28.32)$ & 65.91 & 11.50 \\
\hline $\mathbf{T}_{3}-T$. harzianum & ST @ $10 \mathrm{~g} / \mathrm{kg}^{-1}$ & $38.10(38.12)$ & 42.27 & 8.60 \\
\hline $\mathbf{T}_{4}-P$. fluorescens & ST @ $10 \mathrm{~g} / \mathrm{kg}^{-1}$ & $45.00(42.13)$ & 31.82 & 7.20 \\
\hline $\begin{array}{l}\mathrm{T}_{5} \text { - Tebuconazole } 50 \%+ \\
\text { Trifloxystrobin } 25 \% \mathrm{WG}\end{array}$ & Drench@1.5g 1-1 water & $28.65(32.36)$ & 56.59 & 10.40 \\
\hline $\begin{array}{l}\mathrm{T}_{6}-\text { Carbendazim } 12 \%+ \\
\text { Mancozeb } 63 \% \mathrm{WP}\end{array}$ & Drench@2g l${ }^{-1}$ water & $32.26(34.61)$ & 51.12 & 9.60 \\
\hline $\mathbf{T}_{7}-$ T.harzianum & $\begin{array}{l}\text { SA @ } 10 \mathrm{kgha}^{-1} \text { with } 50 \mathrm{~kg} \\
\text { vermicompost }\end{array}$ & $43.00(40.98)$ & 34.85 & 7.90 \\
\hline $\mathbf{T}_{8}-P$. fluorescens & $\begin{array}{l}\text { SA @ } 10 \mathrm{kgha}^{-1} \text { with } 50 \mathrm{~kg} \\
\text { vermicompost }\end{array}$ & $52.45(46.40)$ & 20.53 & 7.00 \\
\hline $\begin{array}{l}\mathrm{T}_{9} \text { - Tebuconazole } 50 \%+ \\
\text { Trifloxystrobin } 25 \% \mathrm{WG}\end{array}$ & $\begin{array}{l}\mathrm{ST} @ 1.5 \mathrm{~g} / \mathrm{kg}^{-1}+\text { Drench @ } 1.5 \mathrm{~g} \\
\mathrm{l}^{-1} \text { water }\end{array}$ & $10.76(19.15)$ & 83.70 & 14.20 \\
\hline $\begin{array}{l}T_{10}-\text { Carbendazim } 12 \%+ \\
\text { Mancozeb } 63 \% \text { WP }\end{array}$ & $\begin{array}{l}\mathrm{ST} @ 2 \mathrm{~g} / \mathrm{kg}^{-1}+\text { Drench } 2 \mathrm{~g} \mathrm{l}^{-1} \\
\text { water }\end{array}$ & $12.60(20.79)$ & 80.91 & 13.50 \\
\hline $\mathbf{T}_{11^{-}}$T. harzianum & $\begin{array}{l}\text { ST } 10 \mathrm{~g} / \mathrm{kg}^{-1}+\mathrm{SA} 10 \mathrm{~kg} \mathrm{ha}^{-1} \\
\text { with } 50 \mathrm{~kg} \text { vermicompost }\end{array}$ & $25.13(30.09)$ & 61.92 & 10.8 \\
\hline $\mathrm{T}_{12}-\mathrm{P}$. flurescens & $\begin{array}{l}\text { ST } 10 \mathrm{~g} / \mathrm{kg}^{-1}+\mathrm{SA} 10 \mathrm{~kg} \mathrm{ha}^{-1} \text { with } \\
50 \mathrm{~kg} \text { vermicompost }\end{array}$ & $33.10(35.12)$ & 49.85 & 9.70 \\
\hline $\mathbf{T}_{13}$ - Control & - & $66.00(54.33)$ & - & 5.70 \\
\hline S.Em $( \pm)$ & & 2.08 & & 0.63 \\
\hline $\mathrm{CD}(\mathrm{P}=0.05 \%)$ & & 6.09 & & 1.84 \\
\hline CV $(\%)$ & & 10.99 & & 11.10 \\
\hline
\end{tabular}

\footnotetext{
*Figures in parentheses are angular transformed values;ST- Seed treatment; SA- Soil application;
} 
All the treatments in the field trail were found significantly increased the yield as compared to control. Highest yield of mungbeen seed (14.20 $\mathrm{q} / \mathrm{ha}^{-1)}$ was obtained in the treatment of seed treatment in combination of soil drench of tebuconazole $50 \%$ + trifloxystrobin $25 \%$ WG followed by seed treatment in combination of soil drench with carbendazim $12 \%+$ mancozeb $63 \%$ WP $\left(13.50 \mathrm{q} / \mathrm{ha}^{-1}\right)$. Both the treatments were statistically at par. As regards to seed treatment with $T$. harzianum in combination with seed treatment and soil application with $T$. harzianum was also effective and gave (10.8 $\mathrm{q} / \mathrm{ha}^{-1}$ ) yield followed by soil drench of tebuconazole $50 \%$ + trifloxystrobin $25 \% \mathrm{WG}$ $\left(10.40 \mathrm{q} / \mathrm{ha}^{-1}\right)$. As regards to soil application with bioagents it was least effective than the seed treatment. Conclusively, application of the fungicides in combination with seed treatment and soil drench of tebuconazole $50 \%+$ trifloxystrobin 25\% WG enhanced the yield more effectively as compared to other fungicides and bioagent treatment. The study clearly showed that mungbeen grain yield was considerably enhanced due to bioagent treatments used alone or in combinations as seed treatments and soil application. The grain yield was recorded $(10.8 \mathrm{q} / \mathrm{ha})$ in $T$. harzianum seed treatment $\left(10 \mathrm{~g} \mathrm{~kg}^{-1}\right)$ and soil application (10 kg ha ${ }^{-1}$ ) followed by $P$. fluorescens seed treatment plus soil application $(9.70 \mathrm{q} / \mathrm{ha})$. Besides, the combined treatment $T$. harzianum used as seed treatment and soil applications to significantly increase in grain yield. The reduction in soil borne plant diseases and subsequent enhancement in the yield of different crops after treatment with formulations of $T$. harzianum have been reported by several workers (Harman et al., 2004 and Jaiman et al., 2009). Conclusively, the soil application of bioagents in combination with seed treatment with soil drench reduced the disease incidence effectively as compared to sole application of bioagents.

Based on our present studies, it is concluded that treatments consisting with tebuconazole $50 \%+$ trifloxystrobin $25 \%$ WG seed treatment $\left(1.5 \mathrm{~g} / \mathrm{kg}^{-1}\right.$ seed) and soil drenching $\left(1.5 \mathrm{~g} / \mathrm{lt}^{-1}\right.$ water) was found most effective in minimizing the foliar blight incidence (10.76\%), disease inhibition $(83.70 \%)$ and gave highest seed yield $\left(14.20 \mathrm{q} / \mathrm{ha}^{-1)}\right.$ in mungbean followed by treatment consisting with seed treatment of carbendazim 12\% + mancozeb 63\% WP @ 2 $\mathrm{g} / \mathrm{kg}^{-1}$ and soil drenching of carbendazim $12 \%+$ mancozeb 63\% WP @ 2 $\mathrm{g} \mathrm{lt}^{-1}$ water $(12.60 \%)$, $(80.91 \%)$ and $\left(13.50 \mathrm{q} / \mathrm{ha}^{-1}\right)$ as compared to control $\left(66.00 \%\right.$ and $\left.5.70 \quad \mathrm{q} / \mathrm{ha}^{-1}\right)$ respectively.while, in case of bioagents, seed treatment with $T$. harzianum@ $10 \mathrm{~g} / \mathrm{kg}^{-1}$ and combination with soil application @ $10 \mathrm{~kg} \mathrm{ha}^{-1}$ found most effective in minimizing the foliar blight incidence $(25.13 \%)$ and disease inhibition $(61.92 \%)$ followed by seed treatment with $P$. flurescens@10 g/ $\mathrm{kg}^{-1}$ and combination with soil application $10 \mathrm{~kg} \mathrm{ha}^{-1}(33.10 \%)$ and (49.85\%) respectively, as compared to control.

\section{Acknowledgement}

The authors are grateful to the Head of the department, Plant Pathology, College of Agriculture, SKARU, Bikaner for providing the support to undertake the investigation.

\section{References}

Allen. D.J. and Lenne M.J., 1998, Diseases as constraints to production of legumes in agriculture. In pathology of food and pasture legumes of cowpea. Allen, D.J. and Lenne, M.J. (Eds.). CAB International, Wallingford, UK, pp. 267-324.

Anonymous, 2015, FAO, STAT; Bulletin of Tropical Legumes. http//www.icrisat. org/tropical legumes pp11.

Anonymous, 2016, Agriculture Statistics: Directorate of Agriculture. Government of Rajasthan, Jaipur.

Asiwe, J.A.N., 2006, Baseline survey on the production, constraints and utilization of cowpea in South Africa: Implications to cowpea improvement. Proceedings International Conference on indigenous vegetables and legumes: Prospects for 
fighting poverty, hunger and malnutrition. Organized by IPGRI, ICRISAT and ISHS, 12-15 December 2006 in Hyderabad, India. Pp. 621-622.

Blakeman JP, Fokkema NJ., 1982, Potential for biological control of plant diseases on the phylloplane. Annu Rev Phytopathol, 20:167-192.

Brien, C.A., Perez, K. and Davis, R.M., 2008, First report of Rhizoctonia solanion mungbean (Vigna radiata) sprouts in California. Dis. Not. 92(5): 831.

Cothran, R.D., Brown, J.M. and Relyea, R.A., 2013, Proximity to agriculture is correlated with pesticide tolerance: evidence for the evolution of amphibian resistance to modern pesticides. Evol. Appl. 6: 832-841.

Couillerot O., Prigent-Combaret C., Caballero-Mellado J, Mënne-Loccoz Y., 2009. Pseudomonas fluorescens and closely-related fluorescent pseudomonads as biocontrol agents of soil-borne phytopathogens. Lett. Appl. Microbiol. 48:505-512.10.1111/j.1472765X.2009.02566.

De Candolle, A.P., 1815, Memoire sur les rhizoctones, nouveau genre de champignons qui attaque les racines, des plantes et enparticuliercelle de la luzernecutivee. Mem. Mus. D' Hist Nat. 2: 209-216.

Goswami, B. K., Rahaman, M. M., Hoque, A. K. M. A, Bhuyan, K. and Mian, I. H., 2011, Variations in different isolates of Rhizoctonia solani based on temperature and $\mathrm{pH}$. Bangladesh $J$. Agril. Res. 36(3): 389-396.

Harman, G.E., Howell, C.R., Viterbo, A., Chet, I. and Lorto, M., 2004. Trichoderma species opportunistic, avirulent and plant symbionts. Nat. Rev. Microbio. 2: 43-56.

Harman, G.E., Obregon, M.A., Samuels, G.J. and Lorito, M., 2010. Changing models for commercialization and implementation of biocontrol in the developing and the developed world. Plant Dis. 94 (8): 928-939.

Hashim, M.S., and K.S. Devi., 2003, Insecticidal action of the polyphenolic rich fractions from the stem bark Streblusasperon dysdercuscingulatus. Fitoterapia, 744:670-676.

Jaiman, R.K., Jain, S.C. and Sharma, P., 2009, Field evaluation of fungicides, bioagents and soil amendments against root rot caused by Macrophomina phaseolina in clusterbean. J. Mycol. Pl. Pathol. 39 (1): 74-76.

Jhamaria, S.L. and Sharma, O.P., 2002, Management of web blight of mung bean through chemicals and plant product. Indian Phytopathol. 55(4): 526.

Kumari, R., Shekhawat, K.S., Gupta, R. and Khokhar, M.K., 2012, Integrated management against root-rot of mungbean [Vigna radiata (L.) Wilczek] incited by Macrophomina phaseolina. Plant Pathol. Microb. 3 (5): 136-140.

Loo, Y. L., Skell, P.S., Thornberry, H.H., Ehrlich, J., McGuire, J.M., Savage, G.M. and Sylvester, C., 1945, Assay of steptomycin by the paper disc plate method. J. Bact. 50: 701-709.

Manu, T. G., Nagaraja, A., Chetan S. Janawad, Hosamani, V., 2012, Efficacy of fungicides and biocontrol agents against Sclerotium rolfsii causing foot rot disease of finger millet, under in vitro conditions. Global J. Biol. Agri. Health Sci., 1: 46-50.

Meena, A.K., and Gangopadhyay, S., 2016. In vitro and in vivo evaluation of antagonistic potential of fungal and bacterial bioagents against Macrophomina phaseolina causing dry root rot in Clusterbean. Indian Phytopathol.69 (4s): 486-490.

Nawar, L.S., 2008, Control of root rot of greenbean with composted rice straw 
fortified with Trichoderma harzianum. American- eurasian J. Agric. \& Environ. Sci. 3(3): 370 - 379.

Papavizas, G.C., 1985. Trichoderma and Gliocladium biology, ecology and potential for bio control. Ann.Rev. Phytopath. 23: 23-54.

Patel, M.D., Lal, A.A. and Singh, P.P., 2014, Efficacy of certain bio agents and fungicides against root rot of chilli. Phytopathology. 9(3): 1273-1277.

Reetha, A.K., Pavani, S.L. and Mohan, S., 2014, Ecofriendly management of fungal antagonistic Trichoderma spp. against charcoal rot of sunflower caused by Macrophomina phaseolina (Tassi.) Goid. J. Biopest. 7 (1): 73-76.

Shalini, Narayan, K.P. and Lata Kotasthane A.S., 2006, Genetic relatedness among Trichoderma isolates inhibiting a pathogenic fungi Rhizoctonia solani. African J. Biotech.5: 580-584.

Wahyudi, A.T., Astuti, R.I and Giyanto, 2011, Screening of Pseudomonas sp. Isolated from rhizosphere of soyabean plant as plant growth promoter and biocontrol agent. American J. Agric. Biol. Sci. 134-141.

\section{How to cite this article:}

Ramji Lal Meena, Shankar Lal Godara, Ashok Kumar Meena and Prabhu Narayan Meena. 2018. Evaluation of Efficacy of Different Bioagents and Fungicides against Rhizoctonia solani (Kuhn). Int.J.Curr.Microbiol.App.Sci. 7(09): 3694-3703. doi: https://doi.org/10.20546/ijcmas.2018.709.459 